\title{
5. Changes to children's forms of living in contemporary Portugal
}

\author{
Ana Nunes de Almeida and Vasco Ramos
}

Following Qvortrup's theoretical proposal of considering children as a generation in a binary 'generational order' $(1994,2010)$, this chapter presents and discusses national data depicting children's forms of living in contemporary Portugal. First, using socio-demographic indicators from different sources, a portrait of children as a specific age group (0-14 years old) in the general population will be elaborated, followed by a look at the families they live with and the values parents convey to them. In the second section, we will focus on two case studies, drawing on recent or ongoing research. The first case study highlights pieces of research that tried to capture children's voices during the recent economic crisis. The second focuses on the structural conditions that frame care work and schooling, including the parental/gender division of labour. It will also address the growing role of digital information and communication technologies (ICTs). Classical variables such as age, sex, region of residence and level of schooling are collected, treated and interpreted, as well as others relating to childhood conditions that highlight its sharp diversity. While the chapter takes an extensive and macro approach to children's living conditions, qualitative illustrations from ongoing or recent research projects are put forward to complement the former perspective. A comparative view will often be introduced so that the Portuguese case is framed with regard to other Southern European countries or the EU as a whole.

\subsection{MAIN TRENDS}

\subsubsection{Children as a Specific Age Group in the Portuguese Population}

Over the last decades, the features of the Portuguese population changed dramatically as the country entered the 'second demographic transition' (SDT) at a fast pace (Lesthaeghe, 2010). SDT hypothesizes that all countries will evolve into very low fertility rates and an increasing diversity in family types. Changes are driven by inevitable shifts in norms and attitudes towards reproduction, intimacy and family life in the direction of greater individual freedom 
and self-actualization (Zaidi and Morgan, 2017) Cin across all regions, social or age groups, nor did $t$ always mean a radical break with the past, resulting instead in a complex set of arrangements where the past is entangled with the present. Nevertheless, in terms of its demography, Portugal is unrecognizable from what it was just four decades ago. In the meantime, data collection on population also developed and children were rescued from the statistical quarantine they were subjected to (Qvortrup, 1990). Such were the significant social and scientific advances that enabled the contextualization of childhood as a permanent structural category of society, and that meant acknowledging and granting autonomy to an underrepresented segment of its population.

Statistical data show how ageing is a current feature of the Portuguese population, driven by changes at the top and at the bottom of the demographic pyramid. While momentum was already building from the mid-1960s, fertility and birth rates dropped abruptly from the late 1970s onwards (Cunha, 2014), placing Portugal (and other Southern countries) among the lowest in the European rankings, far distant from countries such as France, Sweden, Ireland, Denmark and the UK. In Portugal, children per woman of a fertile age dropped from 3.1 in the mid-1960s to 1.5 in 1999. Similar trends were observed in other countries like Spain or Greece. In Portugal, fertility rates have been below the generation substitution range since 1983. While figures have wavered up and down in the last 20 years, they sloped sharply during the crisis, something that also happened in Spain and Greece. In 2017, the fertility rate in Portugal was 1.37 (INE, 2018).

While historically higher in the north of Portugal, fertility rates are now higher in the south and the largest cities (Lisbon and Oporto). Due to higher population density, more children are born along the coastline (and on the Madeira and Azores archipelagos) than in the hinterlands. In addition, while in recent decades fewer children are being born, fewer die within the first year. With the widespread generalization of medicalized maternal-childcare, infant mortality rates dropped from an appalling 77.5 per 1000 in 1960, to 2.62 per 1000 in 2017. Finally, changes in life expectancy, which increased from an average of 67.1 years in 1970 to 80.8 years in 2017, also contributed to a lower proportion of children in the overall population (INE, 2018).

In 2017, Statistics Portugal (Instituto Nacional de Estatística, INE) estimated that there were 1423896 children aged 0-14 in Portugal (INE, 2018). One of the most striking changes resulting from the trends mentioned above was a drastic reduction in the number of children and their proportion within the overall population. Over the last four decades, their percentage was almost halved, decreasing from 27.1 per cent in 1977 to 13.9 per cent in 2017. Similar but sharper declines occurred during the same timeframe in Spain, Greece and Italy. Moreover, breaking down this group into subgroups in Portugal shows 
that in 2017, 0-4-year-olds are only 4.1 per cent of the population, 4.7 per cent for the 5-9-year-old bracket and 5.0 per cent for the 10-14-year-old bracket (INE, 2018). Undoubtedly, as in other Southern European countries, children are currently a smaller generational group within the overall population and such changes must be read alongside evolutions in their status as a generational group.

Children became a smaller proportion of the population not merely because of easier access to effective medical contraception. This change was also brought about and reinforced by changing notions of family and conjugality, female identities and expectations, children and schooling. An enlightening figure is a remarkable increase in the average age of mothers at first birth, which changed from 24.9 in 1977 to 29.6 in 2017 (INE, 2018). While delaying maternity is a common trend across Europe, this trend is sharpest in Southern European countries (and less so in Eastern Europe). In Portugal, such an evolution was driven by women's academic success, high rate of labour market participation, and more recently, by the economic crisis. Furthermore, social values matter - children are now perceived as unique human beings, in need of care and protection, a rational choice of a loving couple or an autonomous person. Children are no longer represented as small adults or, as in the past, as supplementary hands for family work. As consistently shown in surveys, they are the core concern of adults with children in Portugal (Almeida, 2011). According to the European Values Study (2008), a high proportion of the Portuguese population agree with the statement that it is 'parents' duty. . .to do their best for their children even at the expense of their own well-being', which highlights that in Portugal parental roles are understood as entailing the full-time dedication of parents. Indeed, the same applies in the Nordic countries and along the entire Southern European belt.

\subsubsection{Children in Families}

As in other contemporary societies, family structures and dynamics in Portugal have become more diverse because of changing values and attitudes towards sexuality, cohabitation, marriage, fertility, and male and female identities. Currently, there is a high diversity of family arrangements and children are brought up in different contexts. Drawing on Census data, we can trace how family arrangements have evolved (Table 5.1).

First, there was an increase in households without a family ('persons living alone'), while 'complex' families (both 'extended' and 'multiple') diminished. Second, while the proportions of 'simple' families (those composed of a family nucleus) remained stable over three decades, their composition is being reconfigured; there is a noticeable decrease in the proportion of couples with children and a significant increase in single-parent households (mostly 
Table 5.1 Distribution of the resident population per type of household (\%)

\begin{tabular}{lllllll}
\hline & \multicolumn{3}{c}{ Total } & \multicolumn{5}{c}{$10-14$-year-olds } \\
\cline { 2 - 7 } & 1991 & 2001 & 2011 & 1991 & 2001 & 2011 \\
\hline Households without a family & 6.5 & 7.9 & 9.9 & 0.6 & 0.5 & 0.3 \\
- persons living alone & 4.4 & 6.2 & 8.3 & 0.0 & 0.0 & 0.0 \\
- several unrelated persons & 2.1 & 1.8 & 1.6 & 0.6 & 0.5 & 0.3 \\
Simple household structures & 71.8 & 75.1 & 75.3 & 78.4 & 81.9 & 84.4 \\
- couples & 67.0 & 69.0 & 66.9 & 73.8 & 76.3 & 74.3 \\
- couples without children & 12.8 & 15.7 & 18.5 & 0.0 & 0.0 & 0.0 \\
- couples with children & 54.2 & 53.3 & 48.5 & 73.8 & 76.3 & 74.3 \\
- single parent & 4.8 & 6.1 & 8.3 & 4.6 & 5.7 & 10.1 \\
- father with children & 0.6 & 0.8 & 1.1 & 0.4 & 0.5 & 1.0 \\
- mother with children & 4.1 & 5.3 & 7.2 & 4.2 & 5.2 & 9.2 \\
Complex household structures & 21.7 & 17.0 & 14.9 & 21.0 & 17.6 & 15.3 \\
- extended families & 14.1 & 10.8 & 8.8 & 13.1 & 10.2 & 8.0 \\
- multiple families & 7.5 & 6.2 & 6.0 & 7.9 & 7.4 & 7.4 \\
\hline
\end{tabular}

Source: INE (2012).

mothers). According to the 2011 Census (INE, 2012), children aged 0-14 were primarily living within families of couples with children ( 75.3 per cent). Still, 15.3 per cent of children under 15 years were living in complex family arrangements, and 10.1 per cent in single-parent families (mainly women). Consequently, and despite the changes, the overwhelming majority of children live with both parents. However, it is also worth noting that in $2017,54.9$ per cent of newborn children were born out of wedlock and that 18.1 per cent were born to non-cohabiting parents.

On the other hand, more and more children under 15 years of age are living in step-families (7.1 per cent in 2011), that is, after the remarriage or new cohabitation of their father or mother, and where parental biological and social ties coexist. Once more, these arrangements are more common in the south than in the north and centre of Portugal. In addition, according to estimates from Statistics Portugal (INE, 2012), most households with children have only one child (57.8 per cent), and households with three or more children amount only to 6.7 per cent. Growing up without siblings is common for Portuguese children, as it is in other Southern and Eastern European countries. However, this contrasts with the experiences of children from countries where numerous offspring are frequent, like Ireland, France, Finland or Belgium. Portugal is presently one of the European champions of 'the only child' pattern. As some authors contend, the 'minimal parental project' (Cunha, 2014) is a compromise 
that combines the expectation of being a parent and the optimum material conditions to accomplish the prevalent two-child ideal norm.

International surveys give important clues to what social values Portuguese parents intend to convey to their children. Interesting similarities and contrasts were found in the European Values Study (2008). As elsewhere across Southern Europe, 'obedience', that is, conformism to the norm or towards an established authority, is an important value. High importance is given to 'hard work', which detaches Portugal from Western European countries and places it closer to Eastern Europe. Conversely, values such as 'imagination' and 'independence' are less valued in Portugal, in contrast to the Nordic countries and Central Europe. While these are not contemporary results, the substantial traits are likely to endure.

\subsection{CASE STUDIES}

\subsubsection{Capturing the Voices of Children During the Crisis}

While progress has been made in the last few years, child poverty remains high in Portugal in comparison with other European countries (a detailed outlook can be found in Chapter 10). Accounts of how the recent crisis had a lasting impact on children's lives were often absent from the media and political discourses. Moreover, some argue that inferior living standards and invisibility from the public fostered a redefinition of childhood, in which children's fundamental rights (to provision and protection) are restricted. This has been countered by several research teams that attempted to give voice to children and young people in matters that concern them, namely about the impact of the crisis on their lives and about what it means to live in poverty.

Such was a study was conducted by a team at Institute of Social Sciences at the University of Lisbon (ICS-UL), commissioned by UNICEF Portugal - The Impact of the Crisis on Portuguese Children (Wall et al., 2015). It aimed to listen to children and report practices and perceptions about how their everyday life experiences were being affected by the drop in family income and rising levels of unemployment. Face-to-face interviews were carried out at home with 77 children of two age groups (8-12 and 14-17) during the spring of 2013. The qualitative sample ensured diversity of childhood conditions: it involved boys and girls, living in urban, suburban and rural areas of north/ central/south Portugal, living in different family forms (couples, reconstructed and single-parent families) of upper, middle and working classes.

One interesting result was that children perceived crisis as being 'everywhere' around them. Across all social milieu, children were aware of objective and subjective indicators: their parents' workload, unemployment, underemployment, salary cuts and lower family incomes, which very often drastically 
changed consumption patterns of food, clothes and shoes, healthcare, all sorts of domestic products or school materials. Schooling was a sensitive topic: frequently, 'well off' children had to move from private to public schools, and disadvantaged children feared being forced to drop out of school. 'Going to the university', a widespread expectation, was at stake. Parents seemed always 'worried', 'stressed', 'tired', 'working more and more', 'unmotivated'; sometimes they had to migrate, leaving children behind. With parents' worrying about the difficulties of earning a living, children were very much concerned with the quality of relational family environments or affective ties.

Therefore, children shared a multidimensional view of the crisis and, in particular, of poverty. They highlighted not just their material or economic dimensions, but also the risk that these would damage their happiness and emotional well-being. Francisco (9, upper class), related poverty to 'no food' but also to being 'alone'. Maria C. (10, middle class) emphasized, 'a poor child is a child who doesn't have the essential things in life. . . No food and. . perhaps not as much love and affection as I do. . . and she hasn't got such a warm place to live as I have at home'. Inês (12, upper class) mentioned poverty as a synonym for 'lack of food, of a comfortable place to sleep and to be, lack of clothes and of heating. . .lack of happiness'. In addition, Gonçalo (15, working class) explicitly depicted 'poor children' in the following terms: 'They have no love, no affection. . . not enough cuddling'.

Additionally, and contrary to objective indicators, children perceived the crisis as ultimately having an impact on adults, more than on children: 'We don't have to pay, it's our parents. So, in the end, they are the ones who suffer most' (Inês, 12). 'Because they have to pay all the bills and if anyone becomes unemployed, it's them, not us. They earn the money and they take care of the family. Young people do not have the same notions: they only think of themselves' (Rodrigo, 16). Sara (15) summarized this balance quite clearly: 'We study and are preparing our future. . .but it's our parents who carry the burden, they are always thinking I have to work, I have to do this and so that food is not missing at home'.

During this crisis, there were reports of children arriving hungry at school and of canteens staying open during holidays to offer a hot meal for those who needed it. In addition, food banks and other non-governmental organizations (NGOs) reported a record number of applicants for emergency food. Similar accounts popped up in the media in other Western European countries, often mentioning that parents faced the dilemma of choosing between 'heating and eating'. It was against this backdrop that the 'Families and Food in Hard Times 
(FFHT)' project was conceived. ${ }^{1}$ The project studied the experience of family food poverty among low-income families with children and young people aged 11-15 years in three European countries (Portugal, the UK and Norway). Methodologically, it used a case study approach, where parents and children were interviewed. In Portugal, fieldwork took place in three areas (two urban and one rural) within the Greater Lisbon Area.

An innovative feature of FFHT was the inclusion of the experiences of children and young people within family case studies. Children's accounts of their lives highlighted specific aspects of food poverty. One issue relevant to children was social participation around food, which includes family meals, eating out, going over to friends or having them over. Parents and children perceive it as providing a sense of 'normalcy' to families, something that demonstrates that they can engage in common practices within Portuguese society. However, almost all reported compromised social participation around food. For many, eating out with parents once every other month was the only occasion when anyone at home ate out and was a prized treat for the children. While some parents refrained from going out to allow children to do so with friends and colleagues, in some cases children embodied exclusion. For example, Maria I. (12, Lisbon borough) says, 'My colleagues go to [curry shop] on Fridays, and I don't, I have my snack/lunch here [at home]. . . I don't mind not going because I know [mom's] food is better and I don't [think] I would like it and [curry shop] makes me think "hum, it's too expensive and my mom is struggling. She already spent money on me and therefore I lose the will to go". It's not envy, I just don't go'. Others, like Joana F. (15, Lisbon suburb), still prefer hanging out with friends: 'I sometimes leave school and return home with friends. They pass by the church and go buy gum, lollypops, a salty pastry or a latte or something else. I don't eat anything and just watch'.

Although parents try to shield children, they are highly aware of familial constraints and struggles to obtain food. Many are concerned and worry about the lack of food at the house. For example, Maria mentions 'there isn't much money, sometimes I ask for pork chops, and she has less money and can't buy them. [But] Even if. . .even if my mother is really tight, she never let food run out. . . She makes a big effort, works. . .tries to find more clients to have food in the house. . . She's never let there not be food'. Some recalled extreme circumstances of going without food, like Joana M. (13, Lisbon suburb) who told us: 'We had this month, the beginning of April, we had no food in the house because she [mother], they didn't get paid, and my stepfather also took time getting paid'. Her family managed to get emergency help from a food bank.

\footnotetext{
2019.

For more information see: https://foodinhardtimes.org, accessed 7 October
} 
Nevertheless, her parents' despair made her feel sad and helpless: 'Mom always came with a sad face, because she didn't have money and couldn't buy this or that for dinner, and so we always had to find a way, and I was always sad, because she was sad and I became sad'. Joana would like their shopping to '[last] until the end of the month. Instead of three kilos of rice that she would buy at least six'.

\subsubsection{Carework, Pre-schooling, Schooling and Growing Up Digital}

Since the 1974 revolution, access to school has been massively democratized and universalized in Portugal. However, the same cannot be claimed about pre-school and secondary school. On the one hand, public (or private) pre-school access is not universal for all 4-6-year-olds (in 2016/17, 90.8 per cent were in pre-school); and for even younger ages (0-3), public childcare solutions are scarce, parents having to find informal ones or find a place in the private or third sectors. On the other hand, secondary education (although presently compulsory), only includes 77.6 per cent of children of the corresponding age. Therefore, in Portugal, there are obstacles at the very entrance gates of the pre-school system and, despite steady progress, high dropout and failure rates at the upper levels are still to be overcome. We will thus focus on these two issues: selective access to formal childcare solutions and the unequal opportunities to follow a successful school path, once entering the system. Both affect children's living conditions.

Despite progress made in the pre-schooling rates for 4-6-year-olds, Portugal still ranks below the EU-28 average. Regarding crèches and daycare centres ( $0-3$ years of age), the overwhelming majority are run by not-for-profit institutions, with usage being refunded by the state. While two-thirds of parish councils have good pre-school coverage, private operators in the large metropolitan areas of Lisbon and Oporto are the main providers. Therefore, for many families, the option is to leave children with relatives, although higher-income families mostly opt for formal provision.

On the other hand, these issues cannot be dissociated from parental involvement in paid and unpaid work. In Portugal, men and women have a high level of full-time participation in the labour market, and the dual breadwinner model has been favoured by public policy on a national and European level. This feature of Portuguese society is in sharp contrast with many European countries, namely with those in Southern Europe where female activity rates are generally much lower than men's. While part-time work has increased since the crisis, it remains low in comparative terms (in 2017, 11.3 per cent against the EU-28 average of 20.3 per cent). Portuguese (younger) children have full-time working mothers and fathers. 
Gendered asymmetries in participation levels and intensity of work tend to be more acute when there are small children. However, the case of mothers with small children in Portugal differs from other European countries. According to Eurostat (2019), 79.1 per cent of mothers with children (up to six years of age) are employed, clearly above the EU average of 62.4 per cent and its Southern Europe counterparts. Also, differences in participation in the labour market between men and women only amount to 11.4 per cent, whereas they exceed 20 per cent in most of Europe and reach 40 per cent in Eastern European countries (e.g., Hungary, Slovakia, the Czech Republic). These figures place the problem of reconciling professional and family duties and activities at the forefront of parents' daily lives. Not by coincidence, Portuguese children are among those in Europe who spend the fewest hours with their parents.

Childcare and division of housework are two areas that show the structural framework of gendered inequalities, as women overwhelmingly execute the more repetitive and time-consuming activities. The high level of full-time female participation in the labour market did not substantially change this scenario, and thus many women accumulate paid work, childcare and domestic work. Even though, overall, men have made some progress in this domain, the 'second shift' is a burden for a large number of women (Perista et al., 2016; Wall et al., 2016). For example, according to the recent National Time Use Survey (Perista et al., 2016), women with children spent on average 51 minutes more in care work per day (women: $3 \mathrm{~h} 06 \mathrm{~m}$; men: $2 \mathrm{~h} 15 \mathrm{~m}$ ). Also, when looking at the types of activities performed by men and women for at least one hour every day, men's engagement is closer to women's in activities such as reading, playing and chatting and less substantial regarding feeding or helping with baths.

For many families, having fewer children meant that it was possible to make a durable investment in terms of affection and education. The 'educative mobilization of families', that is, 'focus on academic achievement' is a trait of Portuguese society: children's 'métier d'enfant' mostly coincides with their 'métier d'élève' (Perrenoud, 2017; Sirota, 1993). As elsewhere, children in Portugal spend a significant portion of their time in school, and from a very early age. However, not all have the same opportunity to achieve a successful career inside the system.

Regarding academic achievement in mandatory education, in recent years the Ministry of Education has used 'direct courses of success' indicators, which account for students that obtained a positive classification in national tests (Portuguese and mathematics), after a course with no grade retentions in the preceding school years. For the 2016-18 period, the direct courses of success in the 9th grade amounted to 43.9 per cent of all students. However, there are relevant differences between girls and boys. For example, in 2016-17 it amounted to 51 per cent for girls and 41 per cent for boys, revealing that the 
gender gap has been widening. The socio-economic status of families is also a determining factor: successful trajectories are much less common among students supported by the School Social Action Programme (ASE) (in 2016-17 only 22 per cent of ASE Level A and 34 per cent among ASE Level B). ${ }^{2}$

Distinct arguments have been put forward to explain the school gender gap (Almeida and Vieira, 2006; Ribeiro, 2007). One explanation is that girls are encouraged by their mothers' example to progress in an emancipatory path, to accumulate advantages that will protect them from discrimination in the future. Another hypothesis is that, in traditional socialization models, girls are trained to obey, to be disciplined and methodical, and these qualities are essential to succeeding in a traditional and much-feminized school system. Conversely, boys might benefit from socialization patterns with less adult supervision, encouraging them to be independent, ambitious and competitive - qualities that are not favoured in traditional pedagogies.

Meanwhile, children's living conditions in contemporary Western societies are particularly shaped by access to and use of digital ICTs. Portugal is an excellent example of their quick and universal appropriation by families with children (Almeida et al., 2015a). However, the general dissemination of Internet access did not flatten a socially contrasted landscape: inequalities among children are not so much based on the 'haves and have nots' (Livingstone, 2009) but on the different levels of expertise and competence in using them.

At the beginning of the digital boom, parents seemed eager to provide their children with technological devices at home, to enhance and support their educative performance, but also as a means to protect them from the dangers of the public street, especially in urban and suburban areas. 'Digital playgrounds' were put in place, but these parental motivations were very soon overtaken by the children's daily use of that equipment and by the technological progress in itself. As has been highlighted (Almeida et al., 2015a; Ponte et al., 2012) the domestication process of technology impacted how children communicate among peers and construct their identity, combine work and leisure or consumption and production (of digital content) and are involved in a continuous and multidimensional mobility merging in hybrid arrangements of online-offline, virtual-real spheres. On the other hand, portable devices are everywhere: the Internet is a pocket tool, which means that the domestic space is just one, among others, where children access the global world and connect through different platforms. Presently, it can be used 'anywhere,

\footnotetext{
The School Social Action Programme (ASE) supports families based on their income. In 2017-18, Level A support is granted to families with a yearly income of less than $€ 2949$ and Level B for those whose yearly income is between $€ 2949$ and €5899.
} 
anytime', producing reconfigurations of notions of distance, proximity and public-private borders .

A recent research project (Ponte and Batista, 2019) estimated that in 2018, Portuguese children spent, on average, three hours a day using the Internet - and this value is almost the same for boys and girls, but increasing with age (e.g., approximately two hours for 9-10-year-olds, four hours for 15-17-year-olds). Furthermore, smartphones are the more popular device (87 per cent vs 41 per cent for computers), and their use increases with age (57 per cent for 9-10-year-olds, 95 per cent for the oldest). On the other hand, the use of tablets ( 25 per cent overall) is higher among younger age groups (9-10 and 11-12 years old). Concerning the main activities carried out by children, entertainment and communication are at the top: 80 per cent use the Internet to listen to music, to watch videos; and 75 per cent use it to communicate with family and friends or to participate in social media. Online games are mentioned by about 50 per cent of respondents and a gender gap emerges in this activity: two-thirds of the gamers are boys. Almost a third take part in online groups, and a quarter usually read the news or search information for their homework. Civic participation or creative activities (such as content production or editing) are still residual. These are results confirmed by the Health Behaviour in School-aged Children Survey (Matos, 2018) and by a survey commissioned by ANACOM (the Portuguese authority for communications) (Marktest, 2018).

Departing from children's narratives or their ethnographic observation at home, an extensive and qualitative study on children and the Internet (Almeida et al., 2015a) undertaken between 2008 and 2013, confirmed and abundantly illustrated the massive use of these technologies in Portuguese families. Beyond the results mentioned above, it showed children's contribution to their educational scenarios, particularly the role they play in the digital socialization of their parents, ultimately 'beings in the making' (Corsaro, 2005), a status usually attributed to children. Intergenerational relations, depending on contexts, do not always correspond to the very same configurations, the same superior/inferior, master/trainee hierarchies. Children often lead or take part in adults' education.

Indeed, it was demonstrated that families are still, beyond school, important places of production, exchange, transmission, recycling and updating of technical and social knowledge and skills through digital ICTs (Almeida et al., 2013). Social divides are clear, however. In well-off families, young children learn with their parents to use ICTs; adults are their providers, protectors and the supervising participants of their digital learning process; they are all members of active 'networked families'. On the other hand, in low-educated families, children arise as the net generation, and a reversed adult-child relationship is revealed. Children interviewed revealed they become digital 'alone' 
or with their peers, and they are the ones who teach their parents to undertake playful, professional, educational, information and communication activities (i.e., to watch videos, to use Google maps, to find information for a senior course, to create and update a Facebook page). Furthermore, online informal socialization forms (technology mediated) are extremely relevant in children's worlds, but also adults' ones. The multiple forms of entanglement between online-offline mobility, private-public spheres are permanent and contribute to blurring frontiers, once rigid and well defined.

\subsection{FINAL REMARKS}

In this chapter, we used socio-demographic and other data to depict children's changing forms of living in contemporary Portugal. In the last few decades, one of the most significant changes was the actual reduction in the number of children in the total population. With the continued decrease in fertility rates and higher life expectancy, children are currently a smaller group (in proportion) than ever recorded. Intergenerational bonds are reinforced inside the family tree, at the cost of collateral family ties - siblings, cousins, uncles and aunts are rarer in childhood landscapes. By contrast, and from a very early age, children spend long daily hours with their peers at daycare institutions or school.

Social inequalities are a major obstacle to the fulfilment of the UN Convention on the Rights of the Child to protection, provision and participation; they permeate and continue to shape the lives of many children in the present; they put at risk their right to full citizenship in the future. Indeed, a substantial proportion of children in Portugal continue to experience poverty and severe material deprivation. The recent crisis hit children hard, not only because of higher unemployment but because welfare retrenchment meant severe cuts in social support.

Socializing settings changed strikingly. While in Portugal the overwhelming majority of children continue to live in households with two parents, there is a diversification of arrangements and a higher proportion now live in single-parent households. Moreover, many children grow up without siblings. The high level of full-time male and female participation in the labour market, combined with the lack of public daycare and pre-schooling options, is a challenge to parents of many young children, especially in metropolitan areas. As private options are costly, many low-income families mobilize grandparents and other relatives. Additionally, due to gender inequalities in the division of unpaid work, many mothers are burdened with a second shift after work. Children are very often deprived of parental presence and attention, because their parents' working days are long and demanding, inside and outside home. 
The fast dissemination and families' appropriation of digital ICTs had a dramatic impact on children's childhoods, increasingly lived through screens. Different platforms and devices are used on a daily basis (at school, at home, anywhere, anytime), for study, for leisure, to communicate with friends and family. Social networks are places to forge and express identities, virtual and real worlds merging in varied arrangements. Despite equality utopias associated with these new media, inequalities are still pervasive: while access is becoming less of an issue, divides emerge based on how proficiently and creatively children and parents use and interact with technology.

\section{REFERENCES}

Almeida, Ana Nunes de (2011), História da vida privada em Portugal [The History of Private Life in Portugal], Lisbon: Círculo de Leitores.

Almeida, Ana Nunes de, Nuno de Almeida Alves, Ana Delicado and Tiago Carvalho (2013), 'Crianças e internet: a ordem geracional revisitada' [Children and the internet: the generational order revisited], Análise Social, XLVIII(207), 340-65.

Almeida, Ana Nunes de, Ana Delicado and Nuno de Almeida Alves et al. (2015a), Infâncias digitais [Digital Childhoods], Lisbon: Fundação Calouste Gulbenkian.

Almeida, Ana Nunes de, Ana Delicado, Nuno de Almeida Alves and Tiago Carvalho (2015b), 'Internet, children and space: revisiting generational attributes and boundaries', New Media \& Society, 17(9), 1436-53.

Almeida, Ana Nunes de, Ana Sofia Ribeiro and Jussara Rowland (2018), 'Children, citizenship and crisis: towards a participatory agenda', in Marina Costa Lobo, Filpa Carreira da Silva and José Pedro Zúquete (eds), Changing Societies: Legacies and Challenges. Vol. 2: Citizenship in Crisis, Lisbon: Imprensa de Ciências Sociais, pp. 113-34.

Almeida, Ana Nunes de and Maria Manuel Vieira (2006), A escola em Portugal [School in Portugal], Lisbon: Imprensa de Ciências Sociais.

Corsaro, William (2005), The Sociology of Childhood (2nd edition), Thousand Oaks, CA: Pine Forge.

Cunha, Vanessa (2014), 'Quatro décadas de declínio da fecundidade em Portugal' [Four decades of fertility rate decline in Portugal], Inquérito à Fecundidade 2013, Lisbon: INE/FFMS, pp. 19-28.

Diogo, Ana (2013), 'Investimento das famílias em escolarização e contextos escolares' [Research on families in schooling and school contexts], in Ana Diogo and Fernando Diogo (eds), Desigualdades no sistema educativo: percursos, transições, contextos, Lisbon: Mundos Sociais, pp. 89-108.

European Values Study (2008), EVS Survey 2008, accessed 30 September 2019 at https://europeanvaluesstudy.eu/methodology-data-documentation/previous-surveys $-1981-2008 /$ survey-2008/.

Eurostat (2019), Labour Force Survey, accessed 7 October 2019 at https://ec.europa.eu/ eurostat/web/microdata/european-union-labour-force-survey.

Instituto Nacional de Estatística (INE) (2012), Census - Final Results: Portugal-2011, accessed 30 September 2019 at https://www.ine.pt/xportal/xmain?xpid=INE\&xpgid $=$ ine_publicacoes\&PUBLICACOESpub_boui $=73212469 \&$ PUBLICACOESmodo= 2. 
Instituto Nacional de Estatística (INE) (2018), Estatísticas Demográficas - 2017 [Demographic Statistics - 2017]. Lisbon: Instituto Nacional de Estatística.

Lesthaeghe, Ron (2010), 'The unfolding story of the second demographic transition', Population and Development Review, 36(2), 211-51.

Livingstone, Sonia (2009), Children and the Internet, London: Polity.

Marktest (2018), Barómetro de telecomunicações ( $1^{\circ}$ trimestre) [Telecomunnications Barometer (1st trimester)], accessed 9 October 2019 at https://www.marktest.com/ wap/a/grp/p 2.aspx.

Mascheroni, Giovanna and Kjartan Ólafsson (2016), 'The mobile internet: access, use, opportunities and divides among European children', New Media \& Society, 18(8), $1657-79$.

Matos, Margarida (2018), A saúde dos adolescentes portugueses após a recessão [The Health Status of Portuguese Adolescents After the Recession], Health Behaviour in School Aged Children 2018 report.

Perista, Heloísa, Ana Cardoso and Ana Brázia et al. (2016), Os usos do tempo de homens e de mulheres em Portugal [The Uses of Time of Men and Women in Portugal], Lisbon: CESIS/CITE.

Perrenoud, Philippe (2017), Métier d'élève et sens du travail scolaire [Métier d'élève, and a Sense of School Work], Paris: ESF sciences humaines.

Ponte, Cristina and Susana Batista (2019), Usos, competências, riscos e mediações da internet reportados por crianças e jovens (9-17 anos) [Internet Uses, Skills, Risks and Mediations as Reported by Children and Youth (9-17 Years), EU Kids Online and NOVA FCSH.

Ponte, Cristina, Ana Jorge, Jorge Simões and Daniel Cardoso (2012), Crianças e internet em Portugal: acessos, usos, riscos, mediações: resultados do inquérito europeu [Children and the Internet in Portugal: Access, Uses, Risks, Mediations: European Survey Results], EU Kids Online, Coimbra: Minerva.

Qvortrup, Jens (ed.) (1990), Childhood as a Social Phenomenon: An Introduction to a Series of National Reports (19 vols), Vienna: European Centre for Social Welfare Policy and Research.

Qvortrup, Jens (1994), Childhood Matters: Social Theory, Practice and Politics, Aldershot: Avebury.

Qvortrup, Jens (2010), 'A infância enquanto categoria estrutural' [Childhood as a structural category]. Educação e pesquisa, 36(2), 631-44.

Ribeiro, Ana Maria (2007), 'A vantagem escolar das raparigas no secundário: resultados escolares e identidades juvenis numa perspectiva de género' [The advantage of girls in secondary school: school outcomes and youth identities from a gender perspective], in Maria Manuel Vieira (ed.), Escola, jovens e media, Lisbon: Imprensa de Ciências Sociais, pp. 137-62.

Sarmento, Manuel Jacinto, Nátalia Fernándes and Gabriela Trevisan (2015), 'A redefinição das condições estruturais da infância e a crise económica em Portugal' [The redefinition of the structural conditions of childhood and the economic crisis in Portugal], in Fernando Diogo, Alexandra Castro and Pedro Perista (eds), Pobreza e exclusão social em Portugal: contextos, transformações e estudos, Vila Nova de Famalicão: Húmus, pp. 81-99.

Silva, Tiago (2015), A infância em rede: media e quadros de existência infantis na sociedade em rede [Networked Childhood: Media and Children's Frames of Existence in the Age of Network Society], Lisbon: ISCTE-IUL.

Sirota, Régine (1993), 'Note de synthèse' [Le métier d'élève] [A synthesis (Le métier d'élève)], Revue française de pédagogie, 104(1), 85-108. 
United Nations (1989), The United Nations Convention on the Rights of the Child, accessed 30 September 2019 at https://downloads.unicef.org.uk/wp-content/uploads/ 2010/05/UNCRC_united_nations_convention_on_the_rights_of the_child.pdf.

Wall, Karin, Ana Nunes de Almeida and Maria Manuel Vieira et al. (2015), Impactos da crise nas crianças Portuguesas: indicadores, politicas, representações [The Impact of the Crisis on Portuguese Children: Indicators, Policies, Representations], Lisbon: Imprensa de Ciências Sociais.

Wall, Karin, Vanessa Cunha and Susana Atalaia et al. (2016), Livro branco: homens $e$ igualdade de género em Portugal [White Paper: Men and Gender Equality in Portugal], Lisbon: ICS/CITE.

Zaidi, Batool and S. Philip Morgan (2017), 'The Second demographic transition theory: a review and appraisal', Annual Review of Sociology, 43, 473-92. 